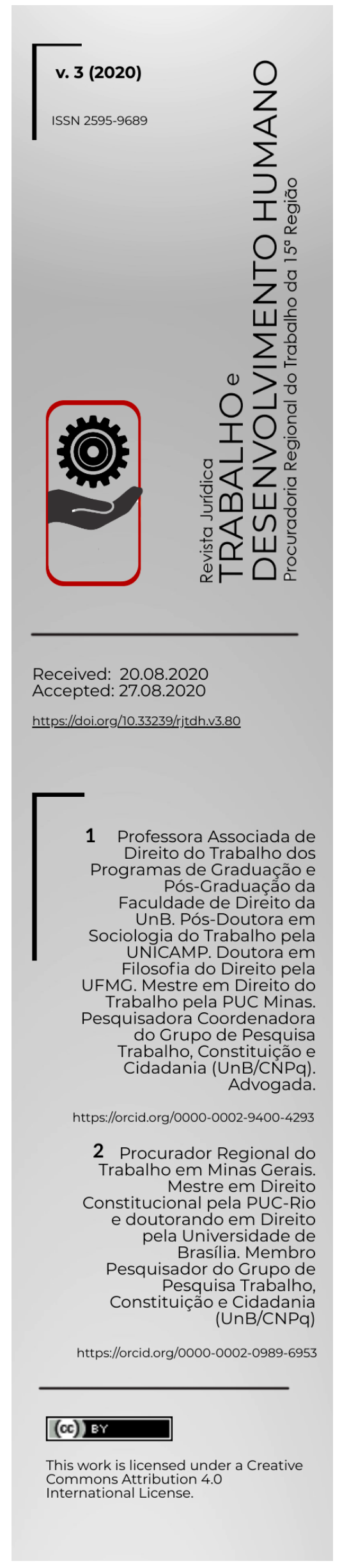

\title{
A legislação pandêmica e o perigoso regime de exceção aos direitos fundamentais trabalhistas
}

\author{
Pandemic legislation and the dangerous exception regard to \\ fundamental labor rights
}

Legislación pandémica y la peligrosa excepción de los derechos laborales fundamentales

\section{Gabriela Neves Delgado' Helder Santos Amorim ${ }^{2}$}

\section{RESUMO}

O presente artigo tem por objeto analisar a legislação trabalhista de emergência editada para enfrentamento da pandemia da Covid-19, consistente nas Medidas Provisórias n. 927 e 936/2020, e suas medidas flexibilizatórias de direitos fundamentais dos trabalhadores, em especial a autorização para celebração de acordos individuais de suspensão contratual e de redução proporcional de jornada e salário, ao largo da negociação coletiva exigida pelo art. 70, $\mathrm{VI}$, da Constituição. Analisa-se a interpretação judicial promovida pelo Supremo Tribunal Federal, em torno da matéria, no julgado cautelar da ADI 6363/DF, que referendou a medida excetiva de direito fundamental, no contexto do amplo movimento jurisprudencial de flexibilização de direitos sociais trabalhistas, levado a cabo pelo Tribunal na última década. $O$ artigo finaliza seu objetivo com uma reflexão sobre os fundamentos da decisão cautelar do STF, apontando neles argumentos que carregam perigoso risco de "contágio argumentativo" flexibilizatório de direitos fundamentais em qualquer cenário de crise econômica, para além do episódio pandêmico, como um alerta de preservação do marco civilizatório e democrático do trabalho firmado pela Constituição de 1988.

PALAVRAS-CHAVES: Legislação. Pandemia. Coronavírus. Covid-19. Redução salarial. Negociação coletiva. Constituição. Direitos fundamentais. Supremo Tribunal Federal. Jurisprudência. Estado Democrático de Direito.

\section{ABSTRACT}

The purpose of this article is to analyze the emergency labor legislation issued to face the Covid-19 pandemic, consistent with Provisional Measures n. 927 and 936/2020, and its flexibilization measures for workers' fundamental rights, in particular the authorization to enter into individual agreements of contractual suspension and proportional reduction of hours and wages, in contradiction to the collective bargaining required by art. $7, \mathrm{VI}$, of the Constitution. The judicial interpretation promoted by the Supreme Federal Court around the matter, is analyzed in the precautionary measure of ADI 6363/DF, which endorsed the exceptional measure of removal of fundamental rights, in the context of the broad jurisprudential movement to relax labor social rights, promoted by the Court in the last decade. The article ends its objective with a reflection on the fundamentals of the STF's precautionary decision, pointing out in them arguments that carry a dangerous risk of "argumentative contagion" flexibilizing fundamental rights in any scenario of economic crisis, in addition to the pandemic episode, as a warning of preservation of the civilizing and democratic framework of work in Brazil, signed by the 1988 Constitution.

KEYWORDS: Legislation. Pandemic. Coronavirus. Covid-19. Wage reduction. Collective agreement. Constitution. Fundamental rights. Supremo Tribunal Federal. Jurisprudence. Democratic State.

\section{RESUMEN}

El propósito de este artículo es analizar la legislación laboral de emergencia editada para enfrentar la pandemia del Covid-19, consistente con las Medidas Provisionales n. 927 y 936/2020, y sus medidas flexibles de derechos fundamentales de los trabajadores, en particular la autorización para celebrar convenios individuales de suspensión contractual y reducción proporcional de jornada y salarios, además de la negociación 
colectiva exigida por el art. 7, VI, de la Constitución. La interpretación judicial impulsada por el Supremo Tribunal Federal, en torno al asunto, se analiza en la sentencia cautelar de ADI 6363 / DF, que avaló la medida de excepción a los derechos fundamentales, en el contexto del amplio movimiento jurisprudencial para relajar los derechos sociales laborales, como se ha realizado por la Corte en la última década. El artículo finaliza su objetivo con una reflexión sobre los fundamentos de la decisión cautelar del STF, señalando en ellos argumentos que conllevan un peligroso riesgo de "contagio argumentativo" flexibilizando derechos fundamentales en cualquier escenario de crisis económica, además del episodio pandémico, como advertencia de preservación del marco civilizador y democrático del trabajo en Brasil, suscrito por la Constitución de 1988.

PALABRAS CLAVE: Legislación. Pandemia. Coronavirus. Covid-19. Reducción de salario. Acuerdo colectivo. Constitución. Derechos fundamentales. Supremo Tribunal Federal. Jurisprudencia. Estado Democratico de Derecho.

Introdução: a legislação pandêmica trabalhista restritiva de direitos fundamentais

O movimento neoliberal de desregulamentação do trabalho ensaiado na década de 1990, no Brasil, retornou com força a partir de 2016, desencadeando as reformas trabalhistas iniciadas com a Lei n. 13.429/2017, que generalizou a terceirização de serviços; depois, na Lei n. 13.467/2017, que implantou a maior reforma flexibilizadora da CLT em mais de setenta anos, alterando e revogando mais de uma centena de dispositivos legais, e na Medida Provisória (MP) n. 881/2019 (MP da Liberdade Econômica), convertida na Lei n. 13.874/2019, que aprofundou a flexibilização do controle de jornada de trabalho. ${ }^{1}$

Foi sob essa agenda reformista neoliberal que, em março de 2020, a pandemia do Sars-CoV-2, o novo coronavírus causador da Covid-19, apanhou o Brasil. A pandemia encontrou um país de dimensão continental com aproximadamente 211 milhões de habitantes, dos quais 100 milhões sem acesso a coleta e tratamento de esgoto e 35 milhões sem acesso a água tratada ${ }^{2}$, um sistema de saúde subfinanciado, com

\footnotetext{
${ }^{1}$ DELGADO, Gabriela Neves; AMORIM, Helder Santos. O perigo de naturalização da legislação trabalhista de emergência na pandemia. Publicado pelo Portal Jota em 06 de julho de 2020. Disponível em: https://www.jota.info/opiniao-e-analise/artigos/o-perigo-de-naturalizacao-da-legislacao-trabalhista-deemergencia-na-pandemia-06072020. Acesso em: 15 ago. 2020.

${ }^{2}$ MUÑOZ, Rafael. O caso do saneamento básico testando novos arranjos para atrair mais investimentos. Folha de São Paulo, São Paulo, 10 de mar. de 2020 . Disponível em: https://www1.folha.uol.com.br/colunas/rafael-munoz/2020/03/o-caso-do-saneamento-basicotestando-novos-arranjos-para-atrair-mais-investimentos.shtml. Acesso em: 07 jun. 2020.
} 
Revista Jurídica Trabalho e Desenvolvimento Humano Procuradoria Regional do Trabalho da 15a Região

investimento congelamento pela Emenda Constitucional (EC) n. 95/2016 ${ }^{3}$, um mercado de trabalho com taxa de desemprego de $12,2 \%$ e taxa de informalidade de $40,6 \%{ }^{4}$ e um aparelho governamental comprometido basicamente com as pautas do mercado, avesso às demandas sociais e sedento por ainda mais desregulação do trabalho.

Em síntese, esse período é marcado por uma série de encadeamentos políticos autoritários $^{5}$ e por um conjunto normativo de manifesto desprezo aos princípios constitucionais da centralidade da pessoa humana, da dignidade, da valorização do trabalho e do emprego e da subordinação da propriedade privada à sua função socioambiental. Caracteriza-se, também, pelo esvaziamento do princípio da igualdade em sentido material, além da desconstrução, direta e indireta, de todo o complexo normativo, constitucional e infraconstitucional, de proteção à saúde e à segurança no trabalho. ${ }^{6}$

Nesse ambiente hostil, o trabalhador brasileiro viu-se desafiado a cumprir a política de distanciamento social recomendada pela Organização Mundial da Saúde (OMS), para prevenção do contágio ao coronavírus.

Com a paralisação de inúmeros setores da atividade econômica, e diante da ameaça concreta de desaceleração econômica, o Estado foi demandado a promover amplas ações de proteção à saúde pública, dentre as quais medidas voltadas a viabilizar e estimular o isolamento social do trabalhador, de modo a prevenir o contágio no ambiente e no deslocamento para o trabalho, preservar o funcionamento de serviços

\footnotetext{
${ }^{3}$ Estima-se que a Emenda Constitucional (EC) n. 95, de 2016, que congelou os gastos da União com despesas primárias por 20 anos, possa ter retirado do sistema de saúde brasileiro investimento público de até R\$ 1 trilhão, conforme estudos do IPEA invocados na Ação Direta de Inconstitucional 5658/DF, proposta pelo Partido Democrático Trabalhista (PDT) em face da referida emenda. BRASIL. Supremo Tribunal Federal, ADI 5658/DF, Rel. Min. Rosa Weber. Pesquisa de Jurisprudência. Disponível em: http://portal.stf.jus.br/processos/detalhe.asp?incidente=5132872. Acesso em: 07 jun. 2020.

4 BRASIL. Instituto Brasileiro de Geografia e Estatística - IBGE. Disponível em: https://www.ibge.gov.br/indicadores\#desemprego. Acesso em: 07 jun. 2020.

${ }^{5}$ A rapidez com que tramitou e foi aprovada a Lei $n$. 13.467/2017, sem qualquer diálogo ou concertação social relevante, é tema bem desenvolvido em artigo científico por Guilherme Camargo Massau e André Kabke Bainy. MASSAU, Guilherme Camargo; BAINY, André Kabke. Diálogo social, pacto social, reforma trabalhista e a proibição do retrocesso: um contrassenso prenunciado. Revista Jurídica Trabalho e Desenvolvimento Humano, Campinas, v. 3, p. 1-34, 2020. Disponível em: https://www.revistatdh.org/index.php/Revista-TDH/article/download/61/42. Acesso em: 12 set. 2020.

${ }_{6}^{6}$ DELGADO, Mauricio Godinho; DELGADO, Gabriela Neves. A Reforma Trabalhista no Brasil: com os comentários à Lei no 13.467/2017. 2. ed. São Paulo: LTr, 2018, p. 41.
} 
Revista Jurídica Trabalho e Desenvolvimento Humano Procuradoria Regional do Trabalho da 15a Região

essenciais no combate à pandemia e, ao mesmo tempo, garantir emprego e renda mínima para manutenção de trabalhadores empregados, autônomos e informais.

Na pandemia, enfim, a preservação do direito ao trabalho tomou urgência angustiante em todo o mundo e, para assegurá-lo, vários países desenvolvidos enfrentam a crise articulando políticas estatais intervencionistas, entre as quais se destacam as medidas de renda mínima e de garantia de emprego. O Brasil, ao contrário, defrontou-se com os desafios da pandemia aprofundando os vazios de proteção social próprios de sua agenda política neoliberal, por meio de uma disciplina normativa repleta de oportunismos. ${ }^{7}$

No campo do Direito do Trabalho, a legislação de emergência adotada pelo governo brasileiro para enfrentamento da pandemia foi inaugurada com a Medida Provisória no 927, de 22 de março de 2020, que tratou apenas do trabalhador empregado, impondo-Ihe exclusivamente os ônus do isolamento social e oferecendo uma série de concessões ao empregador, à custa de intensa flexibilização de direitos trabalhistas. Esse primeiro diploma normativo ofereceu duas ordens de medidas para permitir o isolamento social do trabalhador:

1) facilitou a continuidade das atividades de trabalho no período da pandemia, por meio do teletrabalho em domicílio sem controle de jornada e, portanto, sem limite de tempo de disponibilidade do trabalhador, salvo acordo individual (art. 4으, § 5으); e

2) viabilizou a suspensão das atividades de trabalho, para o que autorizou: a) a antecipação de pausas legais que constituem direitos dos trabalhadores, como a concessão de férias coletivas, a antecipação de férias e feriados (arts. 60 a 13); b) a constituição de um banco de horas, por acordo individual, a ser compensado após a pandemia (art. 14); e c) a suspensão do contrato de trabalho sem remuneração e sem garantia de renda mínima para o trabalhador (art. 18).

Esta última hipótese, referente à possibilidade de suspensão do contrato de trabalho sem garantia de remuneração e de renda mínima para o obreiro, foi revogada

\footnotetext{
7 DELGADO, Gabriela Neves; AMORIM, Helder Santos. O perigo de naturalização da legislação trabalhista de emergência na pandemia. Portal Jota, 06 de julho de 2020. Disponível em: https://www.jota.info/opiniao-e-analise/artigos/o-perigo-de-naturalizacao-da-legislacao-trabalhista-deemergencia-na-pandemia-06072020. Acesso em: 15 ago. 2020.
} 
de imediato pelo art. 2 da MP no 928, publicada em 23 de março de 2020, diante da ampla indignação social e política que a medida ensejou, por seu caráter radicalmente antissocial. A regra afrontava as bases do ordenamento constitucional vigente, com ênfase, na perspectiva principiológica, para os princípios da dignidade da pessoa humana e do valor social do trabalho (CF/88, art. 1으, III e IV), e, na perspectiva dos direitos fundamentais, para os direitos ao salário (art. 7으, IV) e ao seguro social em caso de desemprego involuntário (art. 7으, II).

As demais disposições da MP n. 927/2020 continuaram vigentes, ostentando um arsenal flexibilizatório de segurança social sem precedentes na história do Direito do Trabalho brasileiro, a saber: a) excluiu a Covid-19 como doença ocupacional (art. 29), em prejuízo aos trabalhadores acometidos da doença no ambiente ou no trajeto para o trabalho; b) flexibilizou a fiscalização trabalhista no período da pandemia, reduzindo-a a atividade meramente orientadora e sem caráter punitivo (art. 31); c) prorrogou o pagamento da remuneração de férias (até o quinto dia útil do mês subsequente - art. 9o) e do terço constitucional de férias (até o prazo de pagamento da parcela de gratificação natalina - art. 8ㅇ); d) flexibilizou o controle de jornada no trabalho prestado em regime de teletrabalho, por simples acordo individual (art. 4으, § 5으), apesar da plena possibilidade controle pelos meios telemáticos de comunicação; e) possibilizou a antecipação de um número indefinido de períodos de férias ainda não adquiridas (art. 6 으, § 2으), em prejuízo do direito à recomposição fisiológica do trabalhador nos anos seguintes e sucessivos de atividades sem descanso; f) autorizou o elastecimento da jornada normal, após a pandemia, para compensação do período de paralisação, por meio de banco de horas, mediante acordo individual, contrariamente ao que dispõe o art. 7으, XIII, da Constituição Federal, que exige para tanto a negociação coletiva; e g) possibilitou o elastecimento da jornada em regime $12 \mathrm{~h} \times 36 \mathrm{~h}$ dos profissionais de saúde, para jornadas de até $24 \mathrm{~h} \times 24 \mathrm{~h}$, também mediante simples acordo individual, sem obediência ao mesmo inciso XIII do art. 7o da Constituição.

No julgamento de medida cautelar nas ADI 6342/DF, 6344/DF, 6346/DF, 6352/DF, 6354/DF e 6375/DF, sob relatoria do Ministro Marco Aurélio, o Supremo Tribunal Federal (STF) de plano referendou a constitucionalidade dos dispositivos da MP 
n. 927, à exceção apenas do art. 29, que excluía a Covid-19 como doença ocupacional, e do art. 31, que limitava o exercício da fiscalização trabalhista. Essas regras tiveram a eficácia suspensa por inconstitucionalidade. ${ }^{8}$

As demais medidas restritivas de direitos fundamentais continuaram em vigor, com o beneplácito do STF, ao custo de intensa relativização de direitos fundamentais, ao flexibilizar, por acordo individual, o salário e a jornada, elementos fulcrais do contrato de emprego, determinantes da matriz de regulação civilizatória do trabalho no plano constitucional brasileiro.

Em 17 de junho de 2020, o texto da MP n. 927 foi aprovado pela Câmara dos Deputados (Projeto de Lei de Conversão - PLC n. 18/2020), mas, encaminhado à apreciação do Senado Federal, a medida não foi votada no prazo do § 3 do art. 62 da Constituição, por falta de acordo com o governo, perdendo eficácia em 19/07/2020.

Por conseguinte, embora o estado de calamidade pública decorrente da pandemia esteja decretado até 31/12/2020, nos termos do Decreto Legislativo $\mathrm{n}$. 6/2020, operada a caducidade da MP n. 927, a partir de 20/07/2020 as relações de trabalho voltaram a se submeter ao regramento geral celetista em relação aos temas por ela disciplinados.

A segunda legislação pandêmica tipicamente trabalhista adveio com a Medida Provisória n. 936, de 10 de abril de 2020. Editada dez dias após a MP n. 927, essa legislação veio em resposta à intensa demanda social por uma política estatal de proteção ao emprego e à renda, para permitir o distanciamento social no período da pandemia.

Voltada a atender a típica relação de emprego, a MP n. 936/2020 instituiu o "programa emergencial de manutenção de emprego e renda", que consiste basicamente no pagamento de um seguro social ao empregado, denominado de "benefício emergencial", no período de suspensão do contrato de trabalho, autorizada por até 60 dias (art. 8ㅇ), ou de redução proporcional de jornada e salário (em 25\%, 50\%

\footnotetext{
${ }^{8}$ BRASIL. Supremo Tribunal Federal. Ação direta de inconstitucionalidade $n$ o 6342/DF - Distrito Federal. Relator: Ministro Marco Aurélio Mello. Pesquisa de Jurisprudência, Acórdãos, 29 de abril de 2020. Disponível em: http://portal.stf.jus.br/processos/downloadTexto.asp?id=5071853\&ext=RTF. Acesso em: 06 ago. 2020
} 
Revista Jurídica Trabalho e Desenvolvimento Humano Procuradoria Regional do Trabalho da 15a Região

ou 70\%), por até 90 dias (art. 7ํ).

Paralelamente, a Lei $\mathbf{n} . \mathbf{1 3 . 9 8 2}$, de 2 de abril de 2020, instituiu o programa de auxílio emergencial no valor de $\mathrm{R} \$ 600,00$ (seiscentos reais) mensais, pelo período de 3 meses, destinado a atender trabalhadores autônomos, informais, microempreendedores e desempregados segurados da Previdência Social, vitimados pela drástica redução da atividade econômica e da renda no período de pandemia. É o que demonstra, por exemplo, a pesquisa de campo sobre condições de trabalho de entregadores via plataforma digital durante a Covid-19, retratada em artigo científico com idêntico título, segundo o qual, 58,9\% dos entregadores entrevistados relataram queda remuneratória durante a pandemia de Covid-19. ${ }^{9}$

O programa de seguro social instituído pela MP n. 936, integralmente substitutivo do salário na hipótese de suspensão contratual e parcialmente substitutivo na hipótese de redução proporcional de jornada e salário, implica séria redução na renda do trabalhador, na medida em que o benefício pago pela União não tem vinculação com o salário contratual, tendo por base de cálculo o valor mensal do segurodesemprego a que empregado teria direito em caso de dispensa sem justa causa. Ao se inserir no programa, a depender do valor de seu salário, o empregado pode sofrer redução de sua renda mensal em até $85 \%$ na hipótese de suspensão contratual e em até $59 \%$ em caso de redução proporcional de jornada e salário. ${ }^{10}$

Ainda assim, a MP n. 936 manteve lógica idêntica à da MP n. 927, ao permitir a redução de salário por negociação individual, tanto na hipótese de suspensão contratual, quanto na hipótese de redução proporcional de jornada e salário.

\footnotetext{
${ }_{9}^{9}$ ABÍLIO, Ludmila Costhek; ALMEIDA, Paulo Freitas; AMORIM, Henrique; CARDOSO, Ana Claudia Moreira; FONSECA, Vanessa Patriota da; KALIL, Renan Bernardi; MACHADO, Sidnei. Condições de trabalho de entregadores via plataforma digital durante a Covid-19. Revista Jurídica Trabalho e Desenvolvimento Humano, Campinas, EDIÇÃO ESPECIAL - DOSSIÊ COVID-19, 2020, p. 8. Disponível em: http://www.revistatdh.org/index.php/Revista-TDH/article/view/74/37. Acesso em: 17 set. 2020.

10 Pesquisa de campo sobre as condições de trabalho dos comunicadores no período da pandemia de Covid-19 revela a precarização de suas condições de trabalho, com alta incidência de redução salarial. FIGARO, Roseli; BARROS, Janaina V.; SILVA, Naiana R.; CAMARGO, Camila A.; SILVA, Ana Flávia M.; MOLIANI, João Augusto; OLIVEIRA, Daniela Ferreira de. Como trabalham os comunicadores na pandemia da Covid-19? Revista Jurídica Trabalho e Desenvolvimento Humano, Campinas, EDIÇÃO ESPECIAL DOSSIÊ COVID-19, 2020, p. 4 e 17. Disponível em: http://www.revistatdh.org/index.php/Revista$\mathrm{TDH} /$ article/view/76/43. Acesso em: 17 set. 2020.
} 
O texto original da medida provisória permitiu o acordo individual na pactuação de redução de jornada e salário em percentual de até $25 \%$, e em todas as demais hipóteses de suspensão contratual e de redução de jornada e salário para empregados: a) com remuneração igual ou inferior a 3 salários mínimos (art. 12, l); e b) portadores de diploma de nível superior e com remuneração igual ou superior a duas vezes o teto dos benefícios do Regime Geral de Previdência Social - RGPS (art. 12, II).

Portanto, o diploma normativo somente exigiu a negociação coletiva para empregados com remuneração intermediária entre as hipóteses acima descritas, população que corresponde à menor parcela da força de trabalho empregada no país.

Instado a pronunciar-se sobre a MP n. 936, quanto à constitucionalidade do acordo individual para suspender contrato e reduzir salário, por meio da ADI 6363/DF, o Plenário do STF, apreciando medida cautelar, novamente manteve a eficácia dos dispositivos impugnados.

Com o aval do STF, o texto da MP n. 936 foi aprovado pelo Congresso Nacional e convertido na Lei n. 14.020, de 6 de julho de 2020, que mantém idêntica estrutura da medida provisória quanto ao regime de suspensão contratual e de redução de jornada e salário, com uma pequena restrição adicional ao uso da negociação individual: nas empresas de médio e grande porte (aquelas com receita bruta anual superior a $\mathrm{R} \$$ 4.800.000,00, em 2019) a faixa salarial para incidência do acordo individual foi reduzida de 3 para 2 salários mínimos (art. 12, I).

No mais, os elementos normativos centrais da MP n. 936 foram mantidos, com ampla dispensa de negociação coletiva para os acordos de suspensão contratual e redução salarial, inclusive com autorização ao Poder Executivo para prorrogar os prazos máximos de vigência das medidas. Enfim, por meio do Decreto n. 10.422, de 14/07/2020, o governo federal prorrogou por 30 dias o prazo máximo para redução de jornada e salário e por mais 60 dias o prazo máximo para de acordo de suspensão contratual, de modo a completar, em ambos os casos, o prazo máximo de 120 dias. 
Revista Jurídica Trabalho e Desenvolvimento Humano Procuradoria Regional do Trabalho da 15a Região

1. O aval do STF à legislação de emergência e o perigoso regime de exceção aos direitos fundamentais trabalhistas

Assim que editadas, as MPs n. 927 e 936/2020 foram imediatamente impugnadas no STF por violação a direitos fundamentais trabalhistas garantidos no art. 70 da Constituição, especialmente aqueles relativos à irredutibilidade salarial (inc. VI), à jornada máxima diária e semanal (inc. XIII) e à necessidade de negociação coletiva para flexibilização dessas condições anteriores (inc. XXVI), temas extremamente relativizados pela legislação pandêmica.

Contra dispositivos da MP n. 927/2020 foram propostas as ADIs 6342/DF, 6344/DF, 6346/DF, 6352/DF, 6354/DF e 6375/DF, nas quais o Relator, Ministro Marco Aurélio, indeferiu monocraticamente pedidos de suspensão liminar da eficácia das normas impugnadas. Na decisão monocrática, o Ministro considerou plenamente justificadas as medidas legais, em face da excepcionalidade da situação decorrente da pandemia, ancorado em simples análise prática de custo-benefício diante da considerada gravidade da situação.

Ao analisar a constitucionalidade do art. 3ํ, VI, da MP n. 927, que autorizou o empregador a suspender o cumprimento de exigências administrativas em segurança e saúde no trabalho, norma contrastada com o inciso XXII do art. 70 da Constituição, por exemplo, o Relator entendeu que o dispositivo deveria ser encarado "no sentido de afastar a burocratização dos serviços, exigências que acabem por gerar clima de tensão entre as partes (...)"; sobre a norma do art. $8^{\circ}$ da MP, que autorizou o adiamento do pagamento de remuneração de férias e do respectivo adicional para momento posterior ao gozo, o Relator considerou que a regra apenas teve o "intuito de equilibrar o setor econômico-financeiro"; quanto à norma do $\S 2$ o do art. 14, que autorizou a implementação de banco de horas, por ato patronal, para compensação em período posterior à pandemia, mediante simples acordo individual, regra impugnada em face do inciso XIII do art. 70 da Constituição, que exige negociação coletiva para compensação de jornada, o Relator entendeu justificada a medida na "excepcionalidade do quadro vivenciado no País e, portanto, (n)a conveniência de sopesar-se valores"; em relação ao 
art. 26 da MP, que autorizou a prorrogação da jornada $12 \mathrm{~h} \times 36 \mathrm{~h}$ dos profissionais de saúde, permitindo regime de até $24 \mathrm{~h} \times 24 \mathrm{~h}$, entendeu o Relator "que a disciplina não conflita, de início, com a Constituição Federal (...)". ${ }^{11}$

Submetida a matéria ao Pleno do STF, em sessão finalizada em 29/04/2020, o Tribunal referendou a medida liminar, à exceção apenas do art. 29 da MP n. 927, que excluía a Covid-19 como doença ocupacional, e do art. 31, que limitava o exercício da fiscalização trabalhista. Em relação a essas regras, a maioria dos Ministros acolheu divergência apresentada pelo Ministro Alexandre de Moraes, adotando a suspensão de sua eficácia. ${ }^{12}$

Conforme interpretação atribuída ao voto vencedor pelo portal de notícias do STF (o acórdão ainda não havia sido disponibilizado até o fechamento do presente texto), o art. 29 da MP n. 927, ao prever que casos de contaminação pelo coronavírus não seriam considerados ocupacionais, exceto mediante comprovação de nexo causal, "ofende inúmeros trabalhadores de atividades essenciais que continuam expostos ao risco"; o artigo 31, por sua vez, ao restringir a fiscalização do trabalho, "atenta contra a saúde dos empregados, não auxilia o combate à pandemia e diminui a fiscalização no momento em que vários direitos trabalhistas estão em risco".$^{13}$

Ressalvados esses dispositivos, em relação a todos os demais o Tribunal referendou a decisão do Relator, acolhendo em sede cautelar a constitucionalidade das normas, mediante juízos genéricos de proporcionalidade e excepcionalidade, tais como, "prevaleceu o bom senso, a noção de razoabilidade"; "está-se diante de norma que visa a atender à situação emergencial"; "tem-se a observância da razoabilidade na disciplina,

\footnotetext{
${ }^{11}$ BRASIL. Supremo Tribunal Federal. Ação direta de inconstitucionalidade no 6342/DF - Distrito Federal. Relator: Ministro Marco Aurélio Mello. Pesquisa de Jurisprudência, Decisão Monocrática, 27 de março de 2020, $\quad$ p. $13 . \quad$ Disponível em: http://www.stf.jus.br/arquivo/cms/noticiaNoticiaStf/anexo/ADI6342liminar.pdf. Acesso em: 06 ago. 2020.

${ }^{12}$ BRASIL. Supremo Tribunal Federal. Ação direta de inconstitucionalidade no 6342/DF - Distrito Federal. Relator: Ministro Marco Aurélio Mello. Pesquisa de Jurisprudência, Acórdãos, 29 de abril de 2020. Disponível em: http://portal.stf.jus.br/processos/downloadTexto.asp?id=5071853\&ext=RTF. Acesso em: 06 ago. 2020.

13 Supremo Tribunal Federal. Notícia do STF. Pub. 29/04/2020. Disponível em: http://www.stf.jus.br/portal/cms/verNoticiaDetalhe.asp?idConteudo $=442355 \&$ caixaBusca $=\mathrm{N}$. Acesso em: 22 de jun. 2020. BRASIL. Supremo Tribunal Federal, Pleno. ADI 6342/DF, Rel. Min. Marco Aurélio, Redator Min. Alexandre de Moraes. Pesquisa de Jurisprudência. Data de julgamento DJe 06 mai. 2020.
} 
novamente presente o balizamento no tempo e a pandemia verificada". ${ }^{14}$

Por fim, diante da caducidade da MP n. 927/2020 por decurso de prazo para apreciação pelo Congresso Nacional, referida no tópico anterior, o Procurador-Geral da República peticionou nos autos das respectivas ADIs, sugerindo a extinção do feito por perda de objeto, o que deve se confirmar à luz da jurisprudência da Corte.

Relativamente à MP n. 936/2020, foram impugnados no STF, por meio da ADI 6363/DF, os dispositivos que autorizaram o uso de acordo individual para dispor sobre as medidas de redução de salário e suspensão de contrato de trabalho, ${ }^{15}$ por violação aos arts. 7으, VI, XIII e XXVI, e 8으, III e VI, da Constituição.

Inicialmente, o Relator Ministro Ricardo Lewandowisk concedeu parcialmente a medida cautelar pleiteada, conferindo interpretação conforme à Constituição ao § 4ㅇ do art. 11 da MP n. 936/2020, de modo a esclarecer que os acordos individuais de redução de jornada ou de suspensão contratual deveriam ser comunicados pelos empregadores ao respectivo sindicato laboral, no prazo de até 10 dias, "para que, querendo, deflagre a negociação coletiva, importando sua anuência com o acordado entre as partes".

Para alcançar essa conclusão, o Relator reputou violados os dispositivos constitucionais que exigem negociação coletiva para implementação de medidas que impliquem redução salarial - arts. 7으, VI, XII e XVI, e 8o, III e VI, da Constituição -, considerando o caráter alimentar e a essencialidade do salário e a natureza amplamente compositiva do acordo coletivo, tomado pela Constituição "como forma de administrar crises, viabilizando a própria garantia de emprego". ${ }^{16}$ É o que se extrai do seguinte trecho do julgado:

(...) Pois bem. Tudo indica que a celebração de acordos individuais "de redução da jornada de trabalho e redução de salário ou de suspensão temporária de trabalho", cogitados na Medida Provisória em comento, sem a participação dos sindicatos de trabalhadores na negociação,

\footnotetext{
14 Supremo Tribunal Federal. Notícias do STF. Pub. 29/04/2020. Disponível em: http://www.stf.jus.br/portal/cms/verNoticiaDetalhe.asp?idConteudo=442355\&caixaBusca=N. Acesso em: 22 jun. 2020.

${ }^{15}$ Arts. 1ㅇ, 7으, II, 8으, § 1으 e § 3으, II, 9으, § 1ㅇ, I, 11, § 4으, e 12, caput e parágrafo único.

16 BRASIL. Supremo Tribunal Federal. Ação direta de inconstitucionalidade no 6363/DF - Distrito Federal. Relator: Ministro Ricardo Lewandowski. Pesquisa de Jurisprudência, Decisão Monocrática, 07 abr. 2020, p. 13-14. Disponível em: http://portal.stf.jus.br/processos/downloadPeca.asp?id=1534284710 3\&ext=.pdf. Acesso em: 06 ago. 2020.
} 
parece ir de encontro ao disposto nos arts. 7, VI, XII e XVI, e 8, III e VI, da Constituição.

É que "[o] acolhimento expresso pelo constituinte do princípio da irredutibilidade salarial reafirma o caráter alimentar $\mathbf{e}$ a essencialidade do salário no âmbito da relação jurídica de emprego", ressalvada a sua flexibilização, prevista no próprio regramento constitucional, "mediante negociação coletiva".

Segue-se, portanto, que os acordos coletivos, "[quando] dispuserem sobre redução salarial, inclusive como forma de administrar crises, viabilizado a própria garantia de emprego, serão perfeitamente admitidos pela ordem constitucional". A contrario sensu, não se permite a exclusão das entidades sindicais dos acordos que reduzam salários pela legislação ordinária.

(...)

Por isso, cumpre dar um mínimo de efetividade à comunicação a ser feita ao sindicato laboral na negociação. E a melhor forma de fazê-lo, a meu sentir, consiste em interpretar o texto da Medida Provisória, aqui contestada, no sentido de que os "acordos individuais" somente se convalidarão, ou seja, apenas surtirão efeitos jurídicos plenos, após a manifestação dos sindicatos dos empregados. ${ }^{17}$

Entretanto, no julgamento plenário da medida cautelar, ocorrido em 17/04/2020, a maioria dos ministros da Corte afastou essa decisão monocrática do Relator, seguindo o voto divergente apresentado pelo Ministro Alexandre de Moraes, que admitiu o acordo individual independentemente de participação sindical. ${ }^{18}$

Conforme se depreende da fala do Ministro Alexandre de Moraes na apresentação de seu voto condutor (o acórdão não estava disponibilizado até o fechamento do presente artigo), a excepcionalidade da situação de crise decorrente da pandemia e a necessidade de adoção de medidas emergenciais para preservação de

\footnotetext{
${ }^{17}$ BRASIL. Supremo Tribunal Federal. Ação direta de inconstitucionalidade no 6363/DF - Distrito Federal. Relator: Ministro Ricardo Lewandowski. Pesquisa de Jurisprudência, Decisão Monocrática, 07 abr. 2020, p. 13-14 [grifos no original]. Disponível em: http://portal.stf.jus.br/processos/downloadPeca.asp?id=15342847103\&ext=.pdf. Acesso em: 06 ago. 2020.

${ }^{18}$ BRASIL. Supremo Tribunal Federal. Ação direta de inconstitucionalidade no 6363/DF - Distrito Federal. Relator: Ministro Ricardo Lewandowski. Pesquisa de Jurisprudência, Decisão Monocrática, 17 de abril de 2020, p. 13-14. Disponível em: http://portal.stf.jus.br/processos/downloadPeca.asp?id=15342847103\&ext=.pdf. Acesso em: 06 ago. 2020.
} 
postos de trabalho, sob pena de aprofundamento da crise econômica em escala insuportável, justificaria a adoção excepcional e temporária dos acordos individuais de redução proporcional de jornada e salário, sem a necessidade de anuência sindical.

Na visão dos julgadores, a submissão desses acordos a referendum dos sindicatos ensejaria insegurança jurídica e violação da boa-fé contratual, em face da necessidade de imediata execução do programa emergencial. Iniciada a execução do programa, caso fosse negada a convalidação dos acordos pelos sindicatos, haveria necessidade de posterior devolução do benefício emergencial recebido pelos empregados e de complementação salarial, pelos empregadores.

Ademais, segundo o julgado, a possibilidade de recusa sindical aos acordos individuais reduziria drasticamente a adesão dos empregadores ao programa emergencial, cuja implementação é de interesse público, para evitar o aprofundamento da crise econômica e do desemprego.

À vista dessas considerações, o julgado concluiu que não há, nesta situação, conflito de interesses a ser solvido por meio da intervenção sindical, razão pela qual, o inciso VI do art. 70 da Constituição não deveria ser aplicado isoladamente, mas interpretado teleologicamente com os arts. 1으. III e IV, 3으, II e III, e 6으, caput, da Constituição, que consagram o direito social ao trabalho como fator de preservação da dignidade humana e dos valores sociais do trabalho e da livre iniciativa, e os objetivos de garantir o desenvolvimento nacional e erradicar a pobreza e a marginalização ${ }^{19}$.

É o que se depreende dos seguintes trechos transcritos da fala do Ministro Alexandre de Moraes, na apresentação do seu voto condutor:

(...) Essa análise deve ter como vetor de interpretação, além do art. 70, inciso VI, da Constituição Federal, especialmente, a exposição de motivos da medida provisória assim o demonstra, especialmente os incisos III e IV do art. 1o do texto constitucional, que consagram como fundamentos da República a dignidade da pessoa humana e os valores sociais do trabalho e da livre iniciativa, mas também, como vetores de interpretação, os incisos II e III do art. 3ㅇdo texto constitucional, que proclama como objetivos fundamentais da república, principalmente

19 DELGADO, Mauricio Godinho; DELGADO, Gabriela Neves. A Reforma Trabalhista no Brasil: com os comentários à Lei no 13.467/2017. 2. ed. São Paulo: LTr, 2018, p. 41. 
em tempos dessa crise enorme causada por essa pandemia, garantir o desenvolvimento nacional, erradicação da pobreza e marginalização e redução das desigualdades sociais.

(...) A previsão desse acordo de redução proporcional da jornada de trabalho e salário dos empregados é excepcional, é temporária, pois só pode ser aplicado nesse período, durante o estado de calamidade pública e, repito, a ratio da norma é a manutenção do trabalho, é uma opção ao desemprego, é a valorização da manutenção desse direito social trabalho e, consequentemente, com a complementação do Poder Público, se não chega a $100 \%$, mantém uma renda mínima aos trabalhadores durante esse período e mantém a possibilidade de continuarem ocupando licitamente o seu trabalho, mantendo a dignidade, aquisição de renda para si e para sua família (...). É um período de acomodação e um período de manutenção também das próprias empresas, do empreendedor, para que ele possa continuar mantendo os empregos. Nesse momento, com essa crise aguda que nós tempos, a saúde pública, com essas fortíssimas repercussões sociais e econômicas, me parece absolutamente constitucional e razoável a possibilidade de acordo individual, escrito, entre empregador e empregado (...).

(...) Essa medida provisória, que permite ao empregado uma opção e garante uma parceria entre o empregador, pagando proporcionalmente, e o Poder Público injetando 51,2 bilhões da economia, essa parceria pretende atenuar os efeitos dessa segunda onda. Essa medida provisória, a meu ver, não tem como objetivo, prever uma hipótese específica de redução salarial, onde incidiria de forma única e específica o art. 70, inciso VII [quis dizer VI], da Constituição. Não. $O$ objetivo não foi prever hipóteses de redução salarial. $\mathbf{O}$ objetivo foi estabelecer mecanismos de preservação do emprego e da renda do trabalhador. (...) Não se pretende aqui, nos termos do art. 70, inciso $\mathrm{VI}$, não se pretende reduzir permanentemente, a partir de um conflito entre empregado e empregador, os salários. E essa é a ratio da norma prevista no art. 7으, inciso VI. Quando o art. 70, inciso VI, diz que a redutibilidade salarial só é possível com acordo ou convenção coletiva, prevê a normalidade, a regra, onde há divergência entre os interesses do empregado e dos empregadores (...).

(...) Sem o auxílio do governo e sem essa convergência de interesses entre empregado e empregador, as empresas não sobreviverão a esse período de pandemia (...). Há cálculos mais pessimistas, mais otimistas, mas, na média, que se não houver um auxílio governamental (...) e não houver um pacto entre empregados e empregadores, poderemos terminar essa pandemia, os próximos dois, três meses, entre 25 e 30 milhões de desempregados. Ou seja, é algo inadmissível e gerará um conflito social gigantesco. Então, aqui, insisto, afasto a incidência estrita do art. 7, inciso VI, porque não há 
conflito coletivo, não se pretende tão somente reduzir salário (...).

(...) Se o sindicato tiver essa possibilidade de (...) dizer não concordo, os acordos não são válidos, o empregador terá que complementar os salários e o empregado terá que devolver o benefício que ele recebeu um, dois, três meses do Estado. Veja, qual a segurança jurídica que o empregador terá para fazer esses acordos, podendo daqui quinze, vinte, trinta dias, um mês, dois meses, ou até no final dos três meses, podendo ter que complementar? E complementará como, se as horas trabalhadas não foram as horas integrais? A boa-fé dos participantes estará combalida, a segurança jurídica estará prejudicada. Me parece [sic.], então, que não, que a medida provisória não trouxe como condição resolutiva a participação dos sindicatos (...).

(...) A exigência de que só se torne um ato jurídico perfeito com a concordância do sindicato ou mesmo a possibilidade do sindicato alterar esse acordo feito individualmente, a meu ver, geraria enorme insegurança jurídica e, consequentemente, diminuiria sensivelmente a eficácia dessa medida emergencial, aumentando ou podendo aumentar o desemprego e, não só nesse momento, mas na sequência do fechamento de inúmeras empresas (....). ${ }^{20}$

A leitura isolada dessa decisão, diante do cenário absolutamente inusitado de uma pandemia com forte perspectiva de recessão econômica para cumprimento do isolamento social recomendado pela OMS, naturalmente sugere uma postura judicial ponderada, prudente e compreensiva do imenso desafio que o cenário impõe aos Poderes da República na implementação de esperadas medidas de proteção à saúde pública com preservação do emprego e do equilíbrio econômico.

O recorrente recurso à noção de proporcionalidade, como vetor hermenêutico de compatibilização de interesses conflitantes para resguardar a unidade da Constituição em período de crise, remonta ao exercício de um meticuloso exame de equilíbrio entre as restrições impostas a direitos fundamentais de caráter social e econômico e a correlata necessidade de preservação de bens comuns de relevante interesse público e social, por imperativo constitucional.

Nessa perspectiva, a decisão sugere uma relativização pontual, circunstancial e

\footnotetext{
${ }^{20}$ Transcrição não oficial [grifos acrescidos]. A fala transcrita se encontra entre os minutos 4:28 e 34:52 do vídeo disponível em: https://www.youtube.com/watch?v= LFwWUDURYMQ. Acesso em: 10 ago. 2020.
} 
temporária de garantias constitucionais, vinculada à sua motivação e, por isso, sujeita a interpretação restritiva, condicionada à observância dos motivos determinantes provisórios, inclusive como instrumento de preservação dos próprios direitos afetados. Essa concepção, de certo, é a que confere segurança constitucional à atuação legislativa e governamental restritiva de direitos em período de crise, afiançando a plenitude desses direitos em sua dimensão fundamental, verdadeiro fator de estabilidade do Estado Democrático de Direito. ${ }^{21}$

No entanto, lamentavelmente, essa perspectiva garantista não resiste a um breve exame de coerência no amplo quadro de decisões e posturas que o STF vem adotando na última década, em matéria trabalhista, profundamente redutoras de densidade dos direitos fundamentais sociais inscritos no art. 70 da Constituição, especialmente à vista das últimas decisões proferidas em face de dispositivos da reforma trabalhista implementada pela Lei n. 13.467/2017.

Esse exame contextual revela o perigo de uma interpretação oportunista da legislação pandêmica restritiva de direitos, para aprofundamento do processo de desconstitucionalização dos direitos sociais e econômicos inseridos no Capítulo II - Dos Direitos Sociais - da Constituição de 1988, movimento que o STF tem levado a efeito numa atuação alinhada com o ideário neoliberal, conforme será visto adiante.

Desde a década passada (anos 2000), o STF, em renovadas composições, se lançou num movimento de progressiva atração de matérias trabalhistas em recursos extraordinários que, até então, eram reputadas infraconstitucionais por sua jurisprudência de admissibilidade recursal. No julgamento desses recursos, a Corte passou a tensionar progressivamente a jurisprudência consolidada do Tribunal Superior do Trabalho (TST), em direção a uma flexibilização contínua de direitos, abrindo flanco ao crescimento das demandas empresariais em ações de controle concentrado de constitucionalidade, para obtenção de interpretações redutoras de garantias trabalhistas.

\footnotetext{
${ }^{21}$ Para J.J. Gomes Canotilho, embora o princípio de proibição do retrocesso social nada possa fazer contra as recessões e crises econômicas, ele limita a reversibilidade de direitos adquiridos e do núcleo essencial dos direitos sociais (CANOTILHO, José Joaquim Gomes. Direito constitucional e teoria da Constituição. 7 ed. Coimbra: Almedina, 2006, p. 335).
} 
Revista Jurídica Trabalho e Desenvolvimento Humano Procuradoria Regional do Trabalho da 15a Região

No plano recursal, alguns exemplos desse movimento se encontram nas decisões proferidas no Recurso Extraordinário (RE) 590.415/SC, de 2007 - Tese n. 152 de repercussão geral, que reconhece a quitação ampla do contrato de trabalho em plano de demissão voluntária por meio de norma coletiva, em derrogação ao art. 477, § 2으, da $\mathrm{CLT}^{22}$ no RE 565.714/SP, de 2007 - Tese n. 25 de repercussão geral, que trata da base de cálculo do adicional de insalubridade; no RE 958.252/MG, de 2012, que reconhece a constitucionalidade da terceirização em todas as atividades empresariais, afastando a jurisprudência trintenária do TST (Súmula 331); no ARE 709.212/DF, de 2012 - Tese n. 608 de repercussão geral, que afasta a prescrição trintenária e fixa a tese da prescrição quinquenal do FGTS; no RE 693.456/RJ, de 2012, que determina descontos salariais de dias de greve para os servidores públicos; no ARE 791.932/DF, de 2014 - Tese n. 739 de repercussão geral, que autoriza a ampla terceirização de atividade-fim nas empresas concessionárias de serviço público, e no RE 859.759/PE, de 2015, que reconhece a legalidade da supressão do pagamento de horas in itinere por meio negociação coletiva.

No âmbito do controle concentrado de constitucionalidade, destacam-se decisões que descontruíram fortes pilares da jurisprudência do TST, na última década, a exemplo daquelas proferidas na ADI 3.395/DF, que restringiu a competência da Justiça do Trabalho para julgar demandas de servidores estatutários e, no seu bojo, para apreciar vínculo de emprego nulo subjacente a contratações temporárias irregulares no âmbito da administração pública; na ADI 1.923/DF, em que se reputou constitucional a contratação de atividades tipicamente públicas por meio de organizações sociais; na Ação Declaratória de Constitucionalidade (ADC) 16/DF, que suprimiu a responsabilidade subsidiária automática do Poder Público por inadimplemento de empresas terceirizadas; na Arguição de Descumprimento de Preceito Fundamental (ADPF) 323/DF, que invalidou a Súmula 277 do TST, afastando a ultratividade das normas coletivas; na ADPF 324/DF, em que se reconheceu a constitucionalidade da terceirização irrestrita de atividades, retroativamente, dentre outras.

\footnotetext{
${ }^{22} \S 20$ - O instrumento de rescisão ou recibo de quitação, qualquer que seja a causa ou forma de dissolução do contrato, deve ter especificada a natureza de cada parcela paga ao empregado e discriminado o seu valor, sendo válida a quitação, apenas, relativamente às mesmas parcelas.
} 
Revista Jurídica Trabalho e Desenvolvimento Humano Procuradoria Regional do Trabalho da 15a Região

A partir de 2016, no bojo da discussão legislativa em torno do projeto de reforma trabalhista neoliberal capitaneada pelo novo governo, essa jurisprudência que se consolidava no âmbito do STF conferiu forte subsídio à narrativa de flexibilização de direitos como veículo de geração de emprego, conforme se constata do parecer lançado pelo então Senador Ricardo Ferraço, relator no Senado Federal do Projeto de Lei da Câmara (PLC) n. 38/2017, que deu origem à Lei n. 13.467/2017. ${ }^{23}$

Com a edição da Lei n. 13.467/2017, o STF alçou protagonismo inédito em matéria trabalhista, recebendo mais de 50 (cinquenta) ações de controle concentrado de constitucionalidade em face de dispositivos da reforma e legislação correlata (MP 873/2019), em pelo menos quinze temas fulcrais para o ordenamento jurídico trabalhista. ${ }^{24}$

Dessas ações, até o presente momento, a Corte já referendou a reforma flexibilizadora em dois temas centrais ao projeto neoliberal que encontravam resistência na jurisprudência trabalhista: na ADI 5794/DF, em que o STF declarou a constitucionalidade da extinção da contribuição sindical obrigatória, e nas ADI 5685/DF e 5695/DF, em que o tribunal reconheceu a constitucionalidade da terceirização sem limite, em todas as atividades empresariais, seguindo o precedente firmado no julgamento do RE 958.252/MG e da ADPF 324/DF. Na ADC 58, a pedido do setor

\footnotetext{
${ }^{23}$ Nesse parecer, que foi ao final acolhido, o Senador Ricardo Ferraço invocou a decisão do Supremo Tribunal Federal no RE 590.415/SC, Rel. Min. Roberto Barroso, e no RE 859.759/PE, Rel. Min. Teori Zavaski, em defesa da norma de prevalência do negociado sobre o legislado e das normas que limitaram a atuação sindical; invocou a decisão do STF na ADPF 323/DF, Rel. Min. Gilmar Mendes, em defesa da norma que afastou a ultratividade da norma coletiva. Senado Federal. Parecer (SF) n. 34, de 2017. Senado Federal. Disponível em: https://legis.senado.leg.br/sdleg-getter/documento?dm=5326353\&disposition=inline. Acesso em: 11 ago. 2020.

24 Em face da reforma trabalhista e legislação correlata foram ajuizadas as Ações Diretas de Inconstitucionalidade 5735, 5766, 5794, 5806, 5810, 5811, 5813, 5815,5826, 5829, 5850, 5859, 5865, $5867,5870,5885,5887,5888,5892,5900,5912,5913,5923,5938,5945,5950,5994,6002,6021,6050$, $6069,6082,6092,6093,6098,6099,6101,6104,6105,6107,6108,6114,6115,6142,6154,6188$ e as Ações Declaratórias de Constitucionalidade 55, 58, 59, 62. Essas ações versam sobre terceirização, assistência judiciária gratuita, contribuição sindical, trabalho intermitente, representação de trabalhadores na empresa, correção monetária de depósito recursal, tarifação de indenização por dano moral, trabalho de gestante e lactante em ambiente insalubre, jornada de trabalho, índice de correção monetária de crédito trabalhista, indicação do valor do pedido nas reclamações trabalhistas, procedimento para aprovação de súmulas trabalhistas, negociação coletiva em dispensa coletiva, dentre outros temas. Pesquisa de Jurisprudência. Supremo Tribunal Federal. Disponível em: http://portal.stf.jus.br/. Acesso em: 14 ago. 2020.
} 
Revista Jurídica Trabalho e Desenvolvimento Humano Procuradoria Regional do Trabalho da 15a Região

financeiro, o relator determinou a suspensão de todos os processos trabalhistas que versem sobre o índice de correção monetária aplicável ao crédito trabalhista, até julgamento final da ação. Somente no julgado da ADI 5938/DF a Corte acolheu a inconstitucionalidade de dispositivo que autorizava o trabalho de gestantes e lactantes em ambiente insalubre, matéria de extrema relevância social, mas de pouco impacto na estrutura da regulação do trabalho no país.

Passados mais de três anos da publicação da Lei n. 13.467/2017, todas as demais ações que impugnam dispositivos flexibilizadores de direitos, inclusive aquela que diz respeito ao acesso à Justiça do Trabalho, continuam sem previsão de julgamento, em verdadeiro processo de consumação do fato normativo questionado.

No período posterior à reforma trabalhista, o STF ainda julgou contrariamente aos interesses laborais a ADI 3392/DF, em que reconheceu a constitucionalidade da exigência de comum acordo entre as partes para ajuizamento de dissídio coletivo, e a $A D C 48 / D F$, em que se reconheceu a natureza comercial do vínculo mantido com o transportador autônomo, afastando de forma pressuposta o vínculo de emprego diante de simples observância de formalidades da Lei n. 11.442/2007.

Esse quadro de flexibilização jurisprudencial do Direito do Trabalho se acirra ainda mais à leitura de inúmeras decisões monocráticas proferidas por Ministros do STF em reclamações constitucionais voltadas a garantir a autoridade de suas decisões, em que as interpretações tensionam anda mais, em alto grau, a jurisprudência do TST.

Nesse quadro, o exame contextual das decisões emitidas pela Corte Constitucional acerca da legislação pandêmica, ao invés da esperada postura garantista, revela perigoso indício de aprofundamento de um regime de exceção a direitos fundamentais trabalhistas, a pretexto da crise, especialmente em matéria de Direito Coletivo do Trabalho, como método de consumação do fato normativo antissocial, o "novo normal" de um Direito do Trabalho destituído de alicerce constitucional, posto à inteira disposição dos governos e das maiorias legislativas temporais. ${ }^{25}$

\footnotetext{
${ }^{25}$ A ideia do direito do trabalho de exceção como elemento característico da "sociedade da austeridade" é tema desenvolvido com profundidade em ensaio sociológico do autor português António Casimiro Ferreira (FERREIRA, António Casimiro. Sociedade da Austeridade e Direito do Trabalho de Exceção. Porto: Ed. Vida Económica, 2012).
} 
Cristiano Paixão e Ricardo Lourenço Filho identificam nas decisões do STF acerca da legislação pandêmica, e em especial na decisão cautelar da ADI 6363/DF, que autorizou a suspensão contratual e a redução de jornada e salário mediante acordo individual, mais uma etapa de um movimento judicial ativista de desconstitucionalização dos direitos sociais trabalhistas:

(...) o STF, no campo do direito do trabalho, vem praticando um ativismo judicial da destruição, que ataca diretamente um dos núcleos da Constituição - os direitos sociais. Com decisões dotadas de efeito vinculante e eficácia para todos, o tribunal tem sido um agente da desconstitucionalização. ${ }^{26}$

Esse processo de desconstitucionalização que, para os autores, vem desde decisões que restringiram a greve no serviço público, liberaram a terceirização sem limites e legitimaram a extinção da contribuição sindical obrigatória, tem como resultado a formação de um Direito do Trabalho de exceção: "institui-se, no mundo do trabalho, um espaço de não aplicação da Constituição". ${ }^{27}$

Aliás, para Cristiano Paixão, a própria legislação pandêmica, com as violações constitucionais apontadas, já consiste, por si só, em manifestação do que denomina de "oportunismo desconstituinte", uma postura governamental muito mais ampla, que, a partir de 2016, socorreu-se das crises política, econômica, institucional e, agora, da crise sanitária, para provocar rupturas com as estruturas constitucionais e democráticas, dentre as quais, os direitos sociais, incluindo os direitos dos trabalhadores. ${ }^{28}$

Atentando para a gravidade da afronta constitucional promovida pela MP $\mathrm{n}$. 936/2020, "ao permitir um contrato individual de trabalho para reduzir jornada de trabalho e salário", quando a Constituição exige expressamente para isso a negociação

\footnotetext{
${ }^{26}$ PAIXÃO, Cristiano; LOURENÇO FILHO, Ricardo. O STF e o Direito do Trabalho: as três fases da destruição. Universidade de Brasília. UnB Notícias, 31 de jul. de 2020. Disponível em: https://noticias.unb.br/artigosmain/4332-o-stf-e-o-direito-do-trabalho-as-tres-fases-da-destruicao. Acesso em: 06 ago. 2020.

${ }^{27}$ PAIXÃO, Cristiano; LOURENÇO FILHO, Ricardo. O STF e o Direito do Trabalho: as três fases da destruição. Universidade de Brasília. UnB Notícias, 31 de jul. de 2020. Disponível em: https://noticias.unb.br/artigosmain/4332-o-stf-e-o-direito-do-trabalho-as-tres-fases-da-destruicao. Acesso em: 06 ago. 2020.

${ }^{28}$ PAIXÃO, Cristiano. Destruindo "por dentro": práticas desconstituintes do nosso tempo. Jornal Grupo Gente Nova, 13 jul. 2020. Disponível em: https://iornalggn.com.br/artigos/destruindo-por-dentropraticas-descons tituintes-do-nosso-tempo-por-cristiano-paixao/. Acesso em: 06 ago. 2020.
} 
coletiva, ${ }^{29}$ Cristiano Paixão adverte para o perigo do uso dessa legislação como "janela de oportunidade" para "impor em tempos de emergência, mudanças permanentes nas relações de trabalho", reduzindo ainda mais a função pública do Estado e dos direitos sociais, cuja importância e centralidade a própria crise revela. ${ }^{30}$

Nesse sentido, sobreleva-se a importância do acompanhamento permanente e atento da jurisprudência trabalhista em matéria de legislação pandêmica, pela comunidade de intérpretes da Constituição, em especial a questão relativa aos acordos individuais para suspensão contratual e redução de jornada e salário, de modo a identificar e denunciar eventuais tentativas de naturalização da regra excetiva para além do tempo e das circunstâncias da pandemia, por analogia a situações de crise econômica.

2. O perigo de esvaziamento dos direitos fundamentais à irredutibilidade salarial e à negociação coletiva: de olhos atentos à transição narrativa flexibilizatória

Com a caducidade da MP n. 927/2020, que produziu efeitos até 19/07/2020, restou em vigor a Lei n. 14.020/2020, originária da MP n. 936/2020, e que deixa como legado ultraflexibilizarório da legislação pandêmica do trabalho a primeira autorização legislativa pós-Constituição de 1988 para redução de salário por meio de pacto individual.

Embora no julgado cautelar da ADI 6363/DF o Ministro Relator Alexandre de Moraes ressalte a natureza absolutamente excepcional do programa emergencial da MP 936 como medida temporária e urgente de garantia de postos de trabalho no período da pandemia, por meio de redução de jornada e salário, e com participação financeira

\footnotetext{
${ }^{29}$ BRASIL. Constituição (1988). Constituição da República Federativa do Brasil. Artigo 70, inciso VI. Texto constitucional promulgado em 5 de outubro de 1988, com as alterações adotadas pelas Emendas Constitucionais nos 1/1992 a 76/2013, pelo Decreto Legislativo no 186/2008 e pelas Emendas Constitucionais de Revisão nos 1 a 6/1994. 40.ed. com índice, art. 70, VI. Disponível em: http://www.planalto.gov.br/ccivil 03/constituicao/constituicao.htm. Acesso em: 25 set. 2020.

30 PAIXÃO, Cristiano. Covid-19 e o oportunismo desconstituinte. Jornal Grupo Gente Nova, 09 abr. 2020. Disponível em: https://jornalggn.com.br/artigos/covid-19-e-o-oportunismo-desconstituinte-porcristiano-paixao. Acesso em: 06 ago. 2020.
} 
do Estado, para justificar a alegada incompatibilidade com a negociação coletiva, esse tipo de programa governamental não constitui novidade no ordenamento jurídico brasileiro.

Antes da Constituição de 1988 houve legislação que autorizou redução salarial sem participação sindical em situações de crise financeira. $\mathrm{O}$ art. 503 da CLT autorizou a redução do salário dos empregados em até $25 \%$, por ato do empregador, em caso de força maior ou prejuízos devidamente comprovados. Por sua vez, a Lei n. 4.923/1965 autorizou a redução salarial em razão de conjuntura econômica adversa, mediante negociação coletiva, mas permitindo ao empregador ajuizar ação para obter autorização judicial, caso o sindicato se recusasse à negociação.

Após a Constituição de 1988, que em seu art. 7ํㅡ, VI, garantiu a "irredutibilidade do salário, salvo o disposto em convenção ou acordo coletivo", aquela legislação anterior foi revogada e a legislação posterior, até então, ao instituir programas de manutenção do emprego em períodos de crise econômica, observou a necessidade de prévia negociação coletiva.

A MP n. 2.164-41/2001, que incluiu o art. 476-A à CLT, como medida de incentivo à manutenção do emprego em período de crise financeira, instituiu a possibilidade de suspensão contratual por período de 2 a 5 meses, mediante negociação coletiva, para participação do empregado em curso ou programa de qualificação profissional oferecido pelo empregador, mediante recebimento pelo empregado de uma bolsa-qualificação profissional custeada pelo Fundo de Amparo ao Trabalhador, no valor correspondente ao seguro-desemprego, na forma dos arts. 2--A e 3--A da Lei n. 7.998/1990.

Com idêntico propósito, a MP n. 680/2015, convertida na Lei n. 13.189, de 19/11/2015, instituiu um programa de proteção ao emprego para empresas em dificuldade econômico-financeira, com vigência até $31 / 12 / 2017$, por meio do qual a empresa ficava autorizada a promover redução proporcional de jornada e salário, em até 30\%, por prazo de até 24 meses, mediante negociação coletiva específica (art. 3ㅇ, I, e art. 5ㅇ) , respeitado o limite remuneratório de um salário-mínimo (art. 4으, § 2으). Os empregados atingidos pela medida faziam jus a uma compensação parcial da perda 
salarial a cargo do Fundo de Amparo ao Trabalhador, correspondente a $50 \%$ da persa salarial e limitada a $65 \%$ do valor do seguro-desemprego, no período respectivo.

Como se observa, a legislação nacional já disponibilizou programas de proteção ao emprego para empresas em situação de crise financeira, idênticos àqueles adotados pela MP n. 936, mediante suspensão contratual e/ou redução proporcional de jornada e salário, com aporte de recursos públicos. A única novidade da legislação pandêmica, nesse aspecto, além da dimensão do programa e do curto calendário de adesão, por força da pandemia, é a dispensa da negociação coletiva, rompendo o legislador ordinário, pela primeira vez no cenário pós-Constituição de 1988, com a garantia fundamental da irredutibilidade salarial no plano das relações individuais de trabalho.

Essa ruptura legislativa com aval do STF exerce, pois, forte caráter simbólico, menos em razão do programa emergencial vinculado à pandemia, propriamente, mas pelos elementos de narrativa postos. Aqui, a decisão do STF desloca o fator de flexibilização, da negociação coletiva para o pacto individual, subvertendo a lógica de prevalência das fontes do Direito do Trabalho, fundada no princípio da proteção, e esvaziando a proteção constitucional conferida à negociação coletiva em matéria de irredutibilidade salarial.

O discurso de prevalência do negociado sobre o legislado, próprio do período de discussão da reforma trabalhista de 2017, que apontava a autonomia privada coletiva como nobre instrumento de afirmação democrática, em superação à legislação heterônoma do modelo corporativo-autoritário anterior à Constituição de $1988,^{31}$ dá lugar, no cenário pandêmico, ao discurso de prevalência da autonomia individual do trabalhador

Conforme dito acima, o parecer lançado no PLC n. 38/2017, que deu origem à reforma trabalhista (Lei n. 13.467/2017), para defender os dispositivos que instituiriam a prevalência das normas coletivas flexíveis sobre as rígidas normas estatais (arts. 611A e 611-B da CLT), buscou subsídios em fundamentos adotados pelo STF nos julgados do

\footnotetext{
${ }^{31}$ Conforme parecer do então Senador Ricardo Ferraço, com referências ao julgado do Supremo Tribunal Federal no RE 590.415/SC. Parecer (SF) n. 34, de 2017. Senado Federal. Disponível em: https://legis.senado.leg.br/sdleggetter/ documento ?dm=5326353 \&disposition =inline. Acesso em: 11 ago. 2020
} 
Revista Jurídica Trabalho e Desenvolvimento Humano Procuradoria Regional do Trabalho da 15a Região

RE 590.415/SC, Relator Ministro Roberto Barroso, e da ADPF 323/DF, Relator Ministro Gilmar Mendes, conforme se depreende da seguinte passagem do aludido parecer, que proclama o caráter democrático e essencial da negociação coletiva:

\section{(...) Diz o Ministro Luís Roberto Barroso:}

Assim, se a rigorosa limitação da autonomia da vontade é a tônica no direito individual do trabalho e na legislação infraconstitucional anterior à Constituição de 1988, o mesmo não ocorre no que respeita ao direito coletivo do trabalho ou às normas constitucionais atualmente em vigor. (...)

\section{(...)}

Nesse sentido, é oportuno salientar que o entendimento do PLC n. 38, de 2017, para a questão das negociações coletiva coaduna com aquele do Supremo Tribunal Federal. Afirma o Ministro Gilmar Mendes, em seu voto em medida cautelar na Arguição de Descumprimento de Preceito Fundamental (ADPF) n. 323:

É preciso destacar, desde pronto, que a jurisprudência do Supremo Tribunal Federal tende a valorizar a autonomia coletiva da vontade e da autocomposição dos conflitos trabalhistas, nos termos do art. 7ㅇ, XXVI, da Constituição Federal. ${ }^{32}$

Observe-se que, nesse primeiro plano da argumentação flexibilizatória, o discurso neoliberal enaltece a natureza segura e protetiva da negociação coletiva, como manifestação de uma autonomia coletiva amadurecida e democrática, capaz de equilibrar a relação de poder entre o trabalhador coletivo e o empregador, detentor do aparato econômico. Aqui, a atuação sindical dos trabalhadores comparece com a elevada função de superar a "rigorosa limitação da autonomia da vontade [que] é a tônica no direito individual do trabalho", 33 protegendo o trabalhador individualmente considerado contra a aniquilação de sua autonomia de vontade, em face da pressão econômica.

\footnotetext{
32 BRASIL. Senado Federal. Parecer (SF) n. 34, de 2017, p. 5-6 [grifos acrescidos]. Disponível em: https://legis.senado.leg.br/sdleg-getter/documento?dm=5326353\&disposition=inline. Acesso em: 11 ago. 2020.

${ }^{33}$ BRASIL. Supremo Tribunal Federal. Recurso extraordinário no 590.415/SC - Santa Catarina. Relator: Ministo Roberto Barroso. Pesquisa de Jurisprudência, Acórdãos, 29 de maio de 2015. Disponível em: http://portal.stf.jus.br/processos/downloadPeca.asp?id=306937385\&ext=.pdf. Acesso em: 06 ago. 2020.
} 
De fato, esse pressuposto de hipossuficiência somente foi afastado pela reforma trabalhista na específica hipótese inserida no parágrafo único art. 444 da CLT, que, "no caso de empregado portador de diploma de nível superior e que perceba salário mensal igual ou superior a duas vezes o limite máximo dos benefícios do Regime Geral de Previdência Social", passou a autorizar a livre pactuação entre as partes da relação de emprego sobre temas submetidos, pela regra do art. 611-A da CLT, à flexibilização negocial coletiva.

Mas, dentre esses temas de livre negociação coletiva listados nos incisos da nova norma celetista, sequer consta previsão de negociação sobre redução salarial, restando, por isso, excluída a matéria do rol daquelas passíveis de livre pactuação, na hipótese acima mencionada. Acerca do tema, o § 30 do art. 611-A da CLT apenas dispõe que, se for pactuada cláusula normativa de redução de salário ou jornada, a norma coletiva deverá prever a proteção dos empregados contra dispensa imotivada durante o prazo de vigência do respectivo instrumento.

Observe-se, portanto, que nem na hipótese legal de pressuposta hipersuficiência do trabalhador para flexibilizar por pacto individual direitos previstos em norma heterônoma, inserida pela reforma neoliberal, a redução de salário figura como opção.

Daí que, no discurso de base da legislação pandêmica, mesmo sob fundamento de excepcionalidade, percebe-se um outro (e complementar) movimento de transição narrativa, em que a vontade individual do trabalhador figura como único veículo viável, eficaz e, portanto, legítimo de preservação de seus direitos e, em especial, do seu emprego, ao largo do discurso de insegurança jurídica que se atribui à negociação coletiva em cenário de crise.

No julgado cautelar da ADI 6363/DF, essa ideia central, que afasta a aplicação do inciso VI do art. 70 da Constituição, encontra fundamento em três ordens de argumentos práticos: (a) a negociação coletiva seria incompatível com a urgência na adoção do programa emergencial de enfrentamento da pandemia, para viabilizar o isolamento social com preservação dos postos de trabalho; (b) a contenção da grave crise econômica decorrente da pandemia, como objetivo nacional, afastaria o conflito de interesses entre empregados e empregadores, unindo-os em torno do programa 
subsidiado com recurso governamental para evitar a catástrofe econômica; e (c) ao trabalhador é assegurada a opção de aderir ao programa, vista como única alternativa ao desemprego.

O primeiro argumento, que diz respeito à ausência de tempo hábil para a prática da negociação coletiva, diante da iminência da implementação do grande programa de preservação de emprego, no contexto de pandemia, é o único capaz de sustentar o caráter de absoluta excepcionalidade da interpretação, eis que fundado na necessidade de viabilizar o imediato distanciamento social dos trabalhadores por razão emergencial de saúde pública.

Nessa perspectiva, conforme fundamentos apresentados no voto condutor, fazendo-se urgente o início da implementação do programa, não haveria tempo hábil para finalização de negociações coletivas em torno da suspensão contratual e da redução de jornada/salário. Por conseguinte, iniciada a execução do programa por adesões individuais precárias, sujeitas a referendum sindical, conforme propôs o Ministro Ricardo Lewandowski, eventual negociação coletiva posterior, com caráter de condição resolutiva, implicaria indesejável insegurança jurídica, com risco de baixa adesão ao programa, o que poderia reduzir a eficácia das medidas voltadas ao isolamento social.

Ainda que não se adira ao argumento consequencialista, ele é o único com aderência específica ao fato da pandemia e à necessidade de imediato isolamento social como mais eficiente meio de prevenção, em ambiente de comoção social gerado pela Covid-19, especialmente nos primeiros momentos de sua comunicação ao público.

$\mathrm{Na}$ perspectiva dos autores do presente artigo, a construção intermediária proposta na decisão liminar do Ministro Relator Ricardo Lewandowski era a que compatibilizava com mais precisão os interesses constitucionais envolvidos, em respeito ao direito fundamental dos trabalhadores e com potencial para produzir soluções criativas, por meio do diálogo social. Mas, voltando à preocupação central do artigo sobre o perigo do uso indiscriminado do precedente, há que se reconhecer que esse primeiro fundamento, por sua pertinência específica com o fato da pandemia, é o que menos oferece risco considerável de contágio argumentativo. 
Revista Jurídica Trabalho e Desenvolvimento Humano Procuradoria Regional do Trabalho da 15a Região

Os outros dois outros argumentos, das alíneas b e c, acima apontados, diferentemente, não mantém aderência específica à crise mundial de saúde pública, centrando-se no receio de agravamento da crise econômica dela decorrente. Utilizados isoladamente, tais argumentos justificariam o afastamento de negociação coletiva em qualquer cenário de crise econômica, decorrente de qualquer outra causa e em qualquer outro contexto.

Tais fundamentos carregam elevado risco de contágio argumentativo, com a nefasta naturalização do afastamento da negociação coletiva em situações de crise econômica, o que esvaziaria de forma ordinária e não excepcional o direito fundamental à proteção salarial, correspondendo a verdadeira patologia social de gravíssimas consequências.

Primeiro, analisemos a ideia de que o interesse nacional superior na contenção da grave crise econômica exige a união de empregados e empregadores em torno do programa subsidiado com recurso governamental, como um pacto necessário ao desenvolvimento nacional e à erradicação da pobreza (CF/1988, art. 3ํ, II e III), o que afastaria de forma pressuposta o conflito de interesses entre capital e trabalho (alínea b), dispensando a negociação coletiva. ${ }^{34}$

Essa é uma noção autoritária, que nega a conflituosidade social racionalizada pela Constituição, partindo de uma ultrapassada compreensão integracionista de Estado e sociedade, que conduz a reducionismos, fundamentalismos e autoritarismos. ${ }^{35}$

\footnotetext{
${ }^{34}$ Trecho extraído da fala do Ministro Alexandre de Moraes na apresentação do voto condutor da decisão cautelar na ADI 6363/DF, em julgamento telepresencial ocorrido em 19/04/2020: “(...) Aqui não existe conflito, aqui existe a necessidade de uma convergência, a convergência pela sobrevivência, a convergência pela sobrevivência da empresa, do empregador e do empregado, com o auxílio do governo. Sem o auxílio do governo e sem essa convergência de interesses entre empregado e empregador, as empresas não sobreviverão a esse período de pandemia. (...) se não houver um auxílio governamental (...) e não houver um pacto entre empregados e empregadores, poderemos terminar essa pandemia, os próximos dois, três meses, entre 25 e 30 milhões de desempregados. Ou seja, é algo inadmissível e gerará um conflito social gigantesco. Então, aqui, insisto, afasto a incidência estrita do art. 7, inciso VI, porque não há conflito coletivo, não se pretende tão somente reduzir salário". Transcrição não oficial. A fala completa se encontra entre os minutos 4:28 e 34:52 do vídeo disponível no sítio do YouTube: https://www.youtube.com/watch?v=LFwWUDURYMQ. Acesso em: 10 ago. 2020.

${ }_{35}$ CANOTILHO, José Joaquim Gomes. Direito constitucional e teoria da Constituição. 7. ed. Coimbra: Almedina, 2006, p. 1224.
} 
Ao enunciar o princípio de democracia pluralista, em seu art. 1ํ, V, a Constituição de 1988, segundo José Afonso da Silva, reconhece o pluralismo como uma realidade, "pois a sociedade se compõe de uma pluralidade de categorias sociais, de classes, de grupos sociais, econômicos, culturais e ideológicos". Daí que, para o constitucionalista, "optar por uma sociedade pluralista [tal como o faz a Constituição] significa acolher uma sociedade conflitiva, de interesses contraditórios e antinômicos", constituindo papel do poder político construir o equilíbrio entre essas múltiplas tensões. ${ }^{36}$

Nesse sentido, a concepção negacionista do conflito real entre os interesses de empregados (em manter seus empregos com remuneração integral no período de isolamento social) e empregadores (em manter suas atividades sem solução de continuidade) ignora o caráter compromissório da Constituição democrática de 1988, forjando um consenso, que, a pretexto do enfrentamento da crise social e econômica, nega o pluralismo e o antagonismo de ideias e interesses subjacentes ao pacto fundador, este sim, resultante de um consenso mínimo possível, plasmado nas normas constitucionais, das quais a norma ordinária não pode se afastar, sob pena de ilegitimidade.

No Estado Democrático de Direito, que compreende a conflituosidade permanente, portanto, qualquer pacto entre interesses contrapostos pressupõe uma construção social dialógica. É o que decorre da lição de J. J. Gomes Canotilho:

Considerar a constituição como uma ordem ou sistema de ordenação totalmente fechado e harmonizante significaria esquecer, desde logo, que ela é, muitas vezes, o resultado de um compromisso entre vários actores sociais, transportadores de ideias, aspirações e interesses substancialmente diferenciados e até antagônicos ou contraditórios. O consenso fundamental quanto a princípios e normas positivoconstitucionalmente plasmados não pode apagar, como é óbvio, o pluralismo e antagonismo de ideias subjacentes ao pacto fundador. ${ }^{37}$

\footnotetext{
${ }^{36}$ SILVA, José Afonso da. Curso de Direito Constitucional Positivo. 39. ed. São Paulo: Malheiros, 2016, p. 145.

37 CANOTILHO, José Joaquim Gomes. Direito constitucional e teoria da Constituição. 7. ed. Coimbra: Almedina, 2006, p. 1182 [grifos no original].
} 
Objetar o conflito de classes que subjaz as relações de trabalho na sociedade capitalista, a pretexto de superação de crise econômica, é ideia característica da uma ultrapassada concepção intervencionista e corporativa de Estado, que nega os pressupostos fáticos da economia liberal, restringindo a liberdade sindical e o diálogo social nas relações de trabalho. Essa ideia contradiz, portanto, a própria jurisprudência do STF, ao apregoar a negociação coletiva como o instrumento democrático de flexibilização das normas trabalhistas estatais, inclusive nos momentos de crise, com vistas à adequação setorial negociada.

$\mathrm{O}$ argumento de superioridade do objetivo nacional em período de crise para justificar o afastamento do exercício do direito fundamental à negociação coletiva em matéria de redução salarial (CF/1988, art. 7ำ, VI) somente encontraria algum fundamento constitucional nas excepcionalíssimas hipóteses de decretação de estado de defesa ou de estado de sítio, previstas nos arts. 136 e 137 a 139 da Constituição. Nessas hipóteses, em tese, seria possível a suspensão da liberdade de reunião associativa (CF/1988, art. 136, § 1으, I, a, e art. 139, IV), com restrição de deliberações coletivas, para o cumprimento dos objetivos autorizados pelo Congresso Nacional. ${ }^{38}$ Mas, como bem adverte Cristiano Paixão:

Esses mecanismos, contudo, existem para a defesa da constituição. Eles permitem decisões ágeis, mas impõem prazos para execução das medidas e não desativam os órgãos de controle político e administrativo. E é importante que seja assim, para que se evitem abusos no uso desses instrumentos. Uma crise, por mais grave que seja, não é uma carta branca para alteração permanente da ordem constitucional. ${ }^{39}$

O estado de calamidade pública objeto do Decreto Legislativo n. 6/2020, voltado ao enfrentamento da pandemia de Covid-19 no Brasil, tem por objetivo estrito o alcance de medidas previstas no art. 65 da Lei de Responsabilidade Fiscal - Lei Complementar

\footnotetext{
${ }^{38}$ Conforme parecer emitido pela Ordem dos Advogados do Brasil, de 20 de março de 2020, a pandemia de Covid-19 não justificaria constitucionalmente a decretação de estado de exceção, tendo em vista a existência de meios menos gravosos para o enfrentamento da crise. Conjur, 20.03.2020. Disponível em: https://www.conjur.com.br/dl/estado-sitio-serviria-fragilizar.pdf.Acesso em: 13 ago. 2020.

${ }^{39}$ PAIXÃO, Cristiano. Covid-19 e o oportunismo desconstituinte. Jornal Grupo Gente Nova, 09 de abr. de 2020 [grifos no original]. Disponível em: https://jornalggn.com.br/artigos/covid-19-e-o-oportunismodesconstituinte-por-cristiano-paixao. Acesso em: 06 ago. 2020.
} 
Revista Jurídica Trabalho e Desenvolvimento Humano Procuradoria Regional do Trabalho da 15a Região

n. 101/2000, não tendo o condão de condicionar o exercício de qualquer garantia constitucional. ${ }^{40}$

Mesmo o estado de calamidade pública posteriormente disciplinado pela Emenda Constitucional n. 106, de 7 de maio de 2020, que autoriza a decretação de regime de exceção fiscal, financeiro e de contratações para enfrentamento de calamidade pública nacional decorrente de pandemia, não permite a suspensão de garantias fundamentais. Esse novo regime consiste em mera permissão governamental para gastos suplementares, acima dos limites ordinários de responsabilidade fiscal, revisão de teto de gastos, simplificação de compras e contratações, inclusive de pessoal, e uso de meios excepcionais de alocação de recursos públicos no combate aos problemas econômicos e sociais decorrentes de pandemia.

Contraria a arquitetura constitucional democrática de 1988, portanto, o argumento que afasta a negociação coletiva por alegada ausência de conflito de interesses entre empregados e empregadores, em período de crise econômica, em face de um alegado interesse público nacional superior aos interesses coletivos afetados.

Por fim, o argumento capitulado na alínea c, de que a MP 936 assegurou ao trabalhador a opção de aderir ao programa emergencial, como alternativa ao desemprego ${ }^{41}$, é raciocínio que padece de integridade lógica, por falta de razoabilidade.

Segundo admite a interpretação em análise, ao empregado a quem é proposta adesão ao programa não resta alternativa, senão o desemprego. Mas o desemprego não constitui escolha constitucionalmente legítima de subsistência em cenário de pandemia.

\footnotetext{
${ }^{40}$ Art. 65. Na ocorrência de calamidade pública reconhecida pelo Congresso Nacional, no caso da União, ou pelas Assembleias Legislativas, na hipótese dos Estados e Municípios, enquanto perdurar a situação: I - serão suspensas a contagem dos prazos e as disposições estabelecidas nos arts. 23, 31 e 70; II - serão dispensados o atingimento dos resultados fiscais e a limitação de empenho prevista no art. 9o.

${ }^{41}$ Trecho extraído da fala do Ministro Alexandre de Moraes na apresentação do voto condutor da decisão cautelar na ADI 6363/DF, em julgamento telepresencial ocorrido em 19/04/2020: “(...) Então, a ideia da medida provisória foi oferecer uma opção (...) proporcional e garantidora do trabalho. (...) Obviamente, aqui (...) será uma opção do próprio empregado, o trabalhador pode não querer aceitar esta redução proporcional, receber o auxílio emergencial pra esses 3 meses, e ter a garantia da permanência do seu emprego depois, ele pode não aceitar, e aí na demissão receberá o auxílio, o seguro-desemprego, mas é uma opção lícita, razoável, proporcional que se dá ao próprio empregador, perdão, ao próprio empregado (...)". Transcrição não oficial. A fala completa se encontra entre os minutos 4:28 e 34:52 do vídeo disponível no sítio do YouTube: https://www.youtube.com/watch?v=LFwWUDURYMQ. Acesso em: 10 ago. 2020.
} 
Portanto, a hipótese contraria logicamente o sentido de opção, que, no Dicionário Aurélio, consiste na ação de escolha "entre duas ou várias coisas". ${ }^{42}$

Ao empregado, isoladamente considerado, a quem é proposta adesão ao programa, não resta opção, porque em sua posição individual frente ao empregador o trabalhador não goza de autonomia da vontade para negociar solução alternativa à suspensão do seu contrato ou à redução de seu salário, com a renda reduzida paga pelo programa governamental, tendo em vista sua condição de absoluta vulnerabilidade social.

Sem a presença do seu sindicato, este empregado não tem força para negociar com seu empregador, por exemplo, o pagamento da ajuda compensatória mensal de que trata o art. 9 da Lei n. 14.020/2020, ${ }^{43}$ voltada a compensar a perda remuneratória, e que pode ser paga pelo empregador sem incidência de tributos, FGTS ou qualquer outra contribuição social, desde que a verba esteja prevista em negociação coletiva "ou no acordo individual escrito pactuado" (§ 1으).

Desconectada da realidade, esta última hipótese normativa, de pagamento de ajuda compensatória por negociação individual, soa a ironia legislativa, mas é plenamente viável por meio de negociação coletiva, assim como a construção de outras soluções intermediárias, na medida do porte econômico do empregador, elemento totalmente desconsiderado pela decisão cautelar na ADI 6363/DF.

Conforme reconhece o STF no julgado paradigmático do RE 590.415/SC, em trecho acima transcrito, repita-se, a negociação coletiva constitui instrumento democrático de adequação setorial das normas trabalhistas exatamente por ser capaz de suprir a "a rigorosa limitação da autonomia da vontade [que] é a tônica no direito individual do trabalho (...)". Essa limitação se aprofunda nos períodos de crise econômica, na medida em que se acentua a taxa de desemprego, submetendo o trabalhador ao aviltamento de suas condições de trabalho em troca da manutenção do

\footnotetext{
${ }^{42}$ DICIONÁRIO ONLINE DE PORTUGUÊS - DICIO. Disponível em: https://www.dicio.com.br/opcao/. Acesso em: 14 ago. 2020.

${ }^{43}$ Art. 9o O Benefício Emergencial de Preservação do Emprego e da Renda poderá ser acumulado com o pagamento, pelo empregador, de ajuda compensatória mensal, em decorrência da redução proporcional de jornada de trabalho e de salário ou da suspensão temporária de contrato de trabalho de que trata esta Lei.
} 
emprego. Portanto, quanto mais acentuado o cenário de crise, maior a importância constitucional e democrática da negociação coletiva.

Levado ao extremo, o argumento da opção ao desemprego retrocede à naturalização do trabalho precário, servil, escravo, prestado em troca de alimentação, o que deve ser repudiado de plano, por absoluto desprezo à dignidade da pessoa humana, centro axiológico de toda regulação constitucional civilizatória do trabalho.

À luz dessas considerações, incumbe à comunidade de intérpretes da Constituição, em permanente vigília à observância dos princípios e regras que protegem a dimensão humana do trabalho, acompanhar com atenção esse movimento argumentativo de ativismo judicial, que excepcionou a negociação coletiva no enfrentamento da crise pandêmica, sob critério não estritamente jurídico, mas predominantemente político, econômico e ideológico.

Trata-se de um movimento situado no segundo e último plano da argumentação flexibilizatória (lembre-se, o primeiro plano é o da prevalência da norma coletiva sobre a norma heterônoma), que, se levado a uso político indiscriminado em situações de crise econômica, completará o ciclo de transição narrativa entre a proteção heterônoma do salário e a sua total desregulação, ao gosto do mercado.

3. Notas finais. Presente e futuro do Direito do Trabalho. A legislação pandêmica vai passar?

A preocupação central do presente artigo, para além do prejuízo que a legislação pandêmica efetivamente causou aos direitos fundamentais trabalhistas, especialmente à irredutibilidade salarial e à negociação coletiva, diz respeito ao "risco de contágio" que essa legislação e, muito especialmente, que a sua intepretação levada a cabo pelo STF, possa causar à natureza fundamental dessas garantias.

A proteção aos direitos fundamentais ao salário e à jornada constitui tema central das lutas sociais e sindicais que conduziram à institucionalização e à consolidação do Direito do Trabalho, por força de sua estreita relação com o montante de transferência da força de trabalho que se opera na relação empregatícia. 
Exatamente devido a essa centralidade, a Constituição democrática de 1988 exige negociação coletiva para flexibilização dos elementos salário e jornada, a teor dos incisos VI, XIII e XIV de seu art. 7으, que tratam, respectivamente, da irredutibilidade salarial, do elastecimento de jornada mediante regime compensatório de horários, além da jornada em turnos ininterruptos de revezamento.

A negociação coletiva, para além de um direito social reconhecido nos arts. 70, XXVI, e $8 \stackrel{0}{ }, \mathrm{VI}^{44}$ da Constituição, é uma garantia-liberdade assegurada à organização coletiva dos trabalhadores para a conquista de direitos, melhoria de sua condição social de trabalho mas, acima de tudo, para a defesa dos interesses do trabalhador nos momentos de crise e de pressão econômica por aviltamento de suas condições de vida.

A liberdade sindical é garantida por diversas normas internacionais, a exemplo da Declaração da Filadélfia (Constituição da OIT), da Declaração Universal dos Direitos do Homem e do Pacto Internacional dos Direitos Econômicos, Sociais e Culturais, além das Convenções 87, 98 e 154 da OIT, que tratam respectivamente de liberdade sindical em face do Estado (Convenção 87), de liberdade sindical em face do empregador (Convenção 98) e de fomento à negociação coletiva com liberdade sindical (Convenção 154). Dessas, somente a Convenção 87 não foi ratificada pelo Brasil.

Esse bloco de constitucionalidade, integrado pelas normas internacionais que compõem o ordenamento jurídico nacional, asseguram a liberdade sindical não apenas como garantia de existência e organização dos sindicatos, mas, fundamentalmente, como garantia de atuação constitutiva de direitos, no exercício da atividade negocial e na defesa dos interesses das categorias representadas.

A ordem constitucional e internacional reconhece ao sindicato a primazia da negociação coletiva não apenas pela força de coalizão, mas também pelo conhecimento que detém acerca da realidade do setor econômico em que atua a categoria, reunindo as melhores condições para ajudar a construir respostas em situações de crise, especialmente para avaliar, nesse contexto, a necessidade e conveniência da redução salarial como meio de preservação do emprego, à vista da

\footnotetext{
${ }^{44} \mathrm{VI}$ - é obrigatória a participação dos sindicatos nas negociações coletivas de trabalho.
} 
condição econômica de cada setor e de cada empresa.

A proteção salarial da jornada de trabalho por meio de negociação coletiva, em períodos de crise, constitui pedra fundamental do Direito do Trabalho, direito humano em sua gênese, que deve ser constitucionalmente protegido dos embates políticos e das maiorias contingentes, para que crises econômicas e de saúde pública não deixem, para além dos naturais prejuízos econômicos e sociais, um legado de destruição da proteção democrática do trabalho, abrindo fendas no processo civilizatório que reduzam o trabalho humano a mero recurso de sobrevivência, destituído de sua função constitucional protetiva da dignidade humana do trabalhador.

Em tenaz reflexão sobre "o destino do Direito do Trabalho", em artigo com idêntico título publicado em 1957, o saudoso mestre Orlando Gomes advertia para o destino melancólico do Direito do Trabalho, em face do perigo que representava a despersonalização do empregador, com a substituição do patrão-proprietário pelo patrão-anônimo, das empresas de capital aberto, ou pelo patrão-público, das empresas estatais, fenômeno que, em sua análise, dissolvia progressivamente as figuras de uma autêntica relação de trabalho e suas respectivas posições jurídicas. ${ }^{45}$

Passados mais de sessenta anos desde aquela reflexão, o Direito do Trabalho venceu aqueles e muitos outros desafios e sobrevive às várias transformações dos sistemas de produção e de exploração do trabalho na busca permanente por soluções civilizatórias de regulação do trabalho para os novos modelos de produção, como atualmente ocorre com a indústria 4.0.

Mas, esse resistir, agora, mais do que nunca, depende da capacidade de percepção dos novos fatos pelos estudiosos do Direito do Trabalho, para que a mora perceptiva não acarrete atraso na adequada interpretação da realidade, conforme sábia advertência de Orlando Gomes:

Sabido é que os fatos novos não são percebidos imediatamente porque a imagem dos antigos grava-se na retentiva, inspirando conservantismo. Só mais tarde, quando entram num processo de evolução intensa, vêm a ser apreendidos, provocando divergências

\footnotetext{
${ }^{45}$ GOMES, Orlando. O destino do direito do trabalho. In: Revista da Faculdade de Direito do Paraná, vol. 5. Paraná: UFDP, 1957, p. 154. Disponível em: https://revistas.ufpr.br/direito/article/view/6601. Acesso em: 13 ago. 2020.
} 
na sua interpretação. $\mathrm{O}$ atraso na compreensão acarreta a mora no comportamento. Os homens conduzem-se como se ainda vivessem na situação que passou. No comportamento social, a mora na percepção parece determinar a perpetuação da realidade transposta. ${ }^{46}$

Neste momento, o futuro do Direito do Trabalho depende da vigília permanente dos agentes democráticos. ${ }^{47}$

Cabe à comunidade jurídica comprometida com a regulação democrática e civilizatória do trabalho vigiar permanentemente para que os precedentes e interpretações da legislação pandêmica, excetivos de direitos fundamentais sociais, não produzam contágio argumentativo de suas teses ultraflexibilizadoras para além do tempo, comprometendo o futuro do trabalho protegido constitucionalmente para as próximas gerações de trabalhadores.

\section{Referências}

ABÍLIO, Ludmila Costhek; ALMEIDA, Paulo Freitas; AMORIM, Henrique; CARDOSO, Ana Claudia Moreira; FONSECA, Vanessa Patriota da; KALIL, Renan Bernardi; MACHADO, Sidnei. Condições de trabalho de entregadores via plataforma digital durante a Covid19. Revista Jurídica Trabalho e Desenvolvimento Humano, Campinas, EDIÇÃO ESPECIAL - DOSSIÊ COVID-19, 2020. Disponível em: http://www.revistatdh.org/index.php/Revista-TDH/article/view/74/37. Acesso em: 17 set. 2020.

BRASIL. Constituição (1988). Constituição da República Federativa do Brasil. Artigo 7ํ, inciso VI. Texto constitucional promulgado em 5 de outubro de 1988, com as alterações adotadas pelas Emendas Constitucionais nos 1/1992 a 76/2013, pelo Decreto Legislativo no 186/2008 e pelas Emendas Constitucionais de Revisão nos 1 a 6/1994. 40.ed. com índice, art. 7oㅡ, VI. Disponível em: http://www.planalto.gov.br/ccivil 03/constituicao/constituicao.htm. Acesso em: 25 set. 2020.

\footnotetext{
${ }^{46}$ GOMES, Orlando. O destino do direito do trabalho. In: Revista da Faculdade de Direito do Paraná, vol. 5. Paraná: UFDP, 1957, p. 154. Disponível em: https://revistas.ufpr.br/direito/article/view/6601. Acesso em: 13 ago. 2020.

47 DELGADO, Gabriela Neves; AMORIM, Helder Santos. O perigo de naturalização da legislação trabalhista de emergência na pandemia. Publicado pelo Portal Jota em 06 de julho de 2020. Disponível em: $\quad<$ https://www.jota.info/opiniao-e-analise/artigos/o-perigo-de-naturalizacao-da-legislacaotrabalhista-de-emergencia-na-pandemia-06072020> Acesso em: 15 ago. 2020.
} 
BRASIL. Instituto Brasileiro de Geografia e Estatística - IBGE. Disponível em: https://www.ibge.gov.br/indicadores\#desemprego. Acesso em: 07 jun. 2020.

BRASIL. Senado Federal. Parecer (SF) n. 34, de 2017. Disponível em: https://legis.senado.leg.br/sdleg-getter/documento?dm=5326353\&disposition=inline. Acesso em: 11 ago. 2020.

BRASIL. Supremo Tribunal Federal. Ação direta de inconstitucionalidade no 6342/DF Distrito Federal. Relator: Ministro Marco Aurélio Mello. Pesquisa de Jurisprudência, Acórdãos, 29 de abril de 2020. Disponível em:

http://portal.stf.jus.br/processos/downloadTexto.asp?id=5071853\&ext=RTF. Acesso em: 06 ago. 2020.

BRASIL. Supremo Tribunal Federal. Ação direta de inconstitucionalidade no 6342/DF Distrito Federal. Relator: Ministro Marco Aurélio Mello. Pesquisa de Jurisprudência, Decisão Monocrática, 27 de março de 2020. Disponível em: http://portal.stf.jus.br/processos/downloadPeca.asp?id=15342768485\&ext=.pdf. Acesso em: 06 ago. 2020.

BRASIL. Supremo Tribunal Federal. Ação direta de inconstitucionalidade no 6363/DF Distrito Federal. Relator: Ministro Ricardo Lewandowski. Pesquisa de Jurisprudência, Decisão Monocrática, 07 de abril de 2020. Disponível em:

http://portal.stf.jus.br/processos/downloadPeca.asp?id=1534284710 3\&ext=.pdf. Acesso em: 06 ago. 2020.

BRASIL. Supremo Tribunal Federal. Recurso extraordinário no 590.415/SC - Santa Catarina. Relator: Ministro Roberto Barroso. Pesquisa de Jurisprudência, Acórdãos, 29 de maio de 2015. Disponível em:

http://portal.stf.jus.br/processos/downloadPeca.asp?id=306937385\&ext=.pdf. Acesso em: 06 ago. 2020.

CANOTILHO, José Joaquim Gomes. Direito constitucional e teoria da Constituição. 7. ed. Coimbra: Almedina, 2006.

DELGADO, Gabriela Neves; AMORIM, Helder Santos. O perigo de naturalização da legislação trabalhista de emergência na pandemia. Portal Jota, 06 de julho de 2020. Disponível em: https://www.jota.info/opiniao-e-analise/artigos/o-perigo-denaturalizacao-da-legislacao-trabalhista-de-emergencia-na-pandemia-06072020. Acesso em: 15 ago. 2020.

DELGADO, Mauricio Godinho; DELGADO, Gabriela Neves. A Reforma Trabalhista no Brasil: com os comentários à Lei no 13.467/2017. 2. ed. São Paulo: LTr, 2018. 
Revista Jurídica Trabalho e Desenvolvimento Humano Procuradoria Regional do Trabalho da 15a Região

DICIONÁRIO Online de Português - Dicio. Disponível em: https://www.dicio .com.br Lopcao/. Acesso em: 14 ago. 2020.

FERREIRA, António Casimiro. Sociedade da Austeridade e Direito do Trabalho de Exceção. Porto: Ed. Vida Económica, 2012.

FIGARO, Roseli; BARROS, Janaina V.; SILVA, Naiana R.; CAMARGO, Camila A.; SILVA, Ana Flávia M.; MOLIANI, João Augusto; OLIVEIRA, Daniela Ferreira de. Como trabalham os comunicadores na pandemia da Covid-19? Revista Jurídica Trabalho e

Desenvolvimento Humano, Campinas, EDIÇÃO ESPECIAL - DOSSIÊ COVID-19, 2020. Disponível em: http://www.revistatdh.org/index.php/Revista-TDH/article/view/76/43. Acesso em: 17 de set. 2020.

GOMES, Orlando. O destino do direito do trabalho. In: Revista da Faculdade de Direito do Paraná, vol. 5. Paraná: UFDP, 1957. Disponível em: https://revistas.ufpr.br/ direito/article/view/6601. Acesso em: 13 ago. 2020.

MASSAU, Guilherme Camargo; BAINY, André Kabke. Diálogo social, pacto social, reforma trabalhista e a proibição do retrocesso: um contrassenso prenunciado. Revista Jurídica Trabalho e Desenvolvimento Humano, Campinas, v. 3, 2020. Disponível em: https://www.revistatdh.org/index.php/Revista-TDH/article/download/61/42. Acesso em 12 set. 2020.

MUÑOZ, Rafael. O caso do saneamento básico testando novos arranjos para atrair mais investimentos. Folha de São Paulo, São Paulo, 10 de mar. de 2020. Disponível em: https://www1.folha. uol. com.br/colunas/rafael-munoz/2020/03/o-caso-dosaneamento-basico-testando-novos-arranjos-para-atrair-mais-investimentos.shtml. Acesso em: 07 jun. 2020.

PAIXÃO, Cristiano. Covid-19 e o oportunismo desconstituinte. Jornal Grupo Gente Nova, 09 de abr. de 2020. Disponível em: https://jornalggn.com.br/artigos/covid-19-eo-oportunismo-desconstituinte-por-cristiano-paixao/. Acesso em: 06 ago. 2020.

PAIXÃO, Cristiano. Destruindo "por dentro": práticas desconstituintes do nosso tempo. Jornal Grupo Gente Nova, 13 de jul. de 2020. Disponível em:

https://jornalggn.com.br/artigos/destruindo-por-dentro-praticas-descons tituintes-donosso-tempo-por-cristiano-paixao/.Acesso em: 06 ago. 2020.

PAIXÃO, Cristiano; LOURENÇO FILHO, Ricardo. O STF e o Direito do Trabalho: as três fases da destruição. Universidade de Brasília. UnB Notícias, 31 de jul. de 2020. Disponível em: https://noticias.unb.br/artigos-main/4332-o-stf-e-o-direito-dotrabalho-as-tres-fases-da-destruicao. Acesso em: 06 ago. 2020.

SILVA, José Afonso da. Curso de Direito Constitucional Positivo. São Paulo: Malheiros, 
39. ed., 2016.

SUPREMO TRIBUNAL FEDERAL. Notícias do STF. Disponível em:

http://www.stf.jus.br/portal/cms/verNoticiaDetalhe.asp?idConteudo=442355\&caixaB usca $=$ N. Acesso em: 22 jun. 2020.

SUPREMO TRIBUNAL FEDERAL.Pesquisa de Jurisprudência. Disponível em: http://portal.stf.jus.br/. Acessos em 22 jun. 2020 a 19 ago. 2020. 